\title{
Smad4 Decreases the Population of Pancreatic Cancer-Initiating Cells through Transcriptional Repression of ALDH1A1
}

\author{
Yukari Hoshino, ${ }^{*}$ Jun Nishida, ${ }^{*}$ Yoko Katsuno, ${ }^{*}$ Daizo Koinuma, ${ }^{*}$ Taku Aoki, ${ }^{\dagger}$ Norihiro Kokudo, ${ }^{\dagger}$ Kohei Miyazono, ${ }^{*}$ and \\ Shogo Ehata*
}

From the Department of Molecular Pathology, * Graduate School of Medicine, The University of Tokyo, Tokyo; and the Hepato-Biliary-Pancreatic Surgery Division, ${ }^{\dagger}$ Department of Surgery, Graduate School of Medicine, The University of Tokyo, Tokyo, Japan

\author{
Accepted for publication \\ January 6, 2015. \\ Address correspondence to Kohei \\ Miyazono, M.D., Ph.D., Depart- \\ ment of Molecular Pathology, \\ Graduate School of Medicine, \\ The University of Tokyo, 7-3-1 \\ Hongo, Bunkyo-ku, Tokyo \\ 113-0033, Japan. E-mail: \\ miyazono@m.u-tokyo.ac.jp.
}

\begin{abstract}
Cancer progression involves a rare population of undifferentiated cancer-initiating cells that have stem celllike properties for self-renewal capacity and high tumorigenicity. We investigated how maintenance of pancreatic cancer-initiating cells is influenced by Smad4, which is frequently deleted or mutated in pancreatic cancers cells. Smad4 silencing up-regulated the expression of aldehyde dehydrogenase 1A1 (ALDH1A1) mRNA, whereas forced expression of Smad4 in pancreatic cancer cells down-regulated it. Smad4 and ALDH1 expression inversely correlated in some human clinical pancreatic adenocarcinoma tissues, suggesting that ALDH1 in pancreatic cancer cells was associated with decreased Smad4 expression. We then examined whether ALDH1 served as a marker of pancreatic cancer-initiating cells. Pancreatic cancer cells contained $\mathrm{ALDH}_{1}{ }^{\text {hi }}$ cells in $3 \%$ to $10 \%$ of total cells, with high tumorigenic potential. Because Smad4 is a major mediator of transforming growth factor (TGF)- $\beta$ family signaling, we investigated the regulatory mechanism of ALDH activity by TGF- $\beta$ and bone morphogenetic proteins. Treatment with TGF- $\beta$ attenuated ALDH $1^{\text {hi }}$ cells in several pancreatic cancer cells, whereas bone morphogenetic protein- 4 was not as potent. Biochemical experiments revealed that TGF- $\beta$ regulated ALDH1A1 mRNA transcription through binding of Smad 4 to its regulatory sequence. It appears that TGF- $\beta$ negatively regulates ALDH1 expression in pancreatic cancer cells in a Smad-dependent manner and in turn impairs the activity of pancreatic cancerinitiating cells. (Am J Pathol 2015, 185: 1457-1470; http://dx.doi.org/10.1016/j.ajpath.2015.01.011)
\end{abstract}

Among cancer patients, the major causes of mortality are local recurrences and distant metastases. Recent evidence indicates that these events occur because of a specific population of the so-called cancer-initiating cells (CICs), also known as cancer stem cells, which exist within various types of tumors. Therefore, understanding and targeting CICs are essential for improving cancer treatment. CICs are capable of both self-renewal and forming non-CICs to maintain the heterogeneous lineages of cancer cells that comprise the tumor. ${ }^{1}$ This hierarchy produces the diversity and heterogeneity of cancer cells found in tumor tissue. CICs can be identified by expression of cell surface markers, such as CD133 and CD44, by expression of the aldehyde dehydrogenase 1 (ALDH1) enzyme, or as a side population using flow cytometry. ALDH1 oxidizes retinal to retinoic acid and is responsible for resistance against anticancer drugs, such as cyclophosphamide. ${ }^{2}$ ALDH1 expression has been detected in normal stem cells and progenitor cells, ${ }^{3-5}$ as well as in several types of cancers, including breast, lung, colon, diffuse-type gastric, and

Supported by Grant-in-Aid for Scientific Research on Innovative Area (Integrative Research on Cancer Microenvironment Network) grant 22112002 (K.M.); the Global Center of Excellence Program (Integrative Life Science Based on the Study of Biosignaling Mechanisms) from the Ministry of Education, Culture, Sports, Science, and Technology, Japan (K.M.); a specific research grant from the Takeda Science Foundation (K.M.); Grant-in-Aid for Young Scientists (B) grant 22700967 from the Japan Society for the Promotion of Science (S.E.); and Research Fellowship of the Japan Society for the Promotion of Science for Young Scientists grant 24-3881 (Y.H.).

This study was performed in part as a research program of the Project for Development of Innovative Research on Cancer Therapeutics (P-Direct), Ministry of Education, Culture, Sports, Science, and Technology.

Disclosures: None declared. 
pancreatic cancers. ${ }^{6-10}$ High ALDH1 expression correlates with poor prognosis in several types of cancers. ${ }^{8,11}$

Transforming growth factor (TGF)- $\beta$ is the prototypic member of a family of secreted proteins that includes TGF- $\beta$ s, activins, and bone morphogenetic proteins (BMPs). At the cell surface, TGF- $\beta$ binds to two different serine-threonine kinase receptors, type I (T $\beta R I)$ and type II (TRRII), thus exerting many biological functions in both normal and cancer cells. ${ }^{12}$ On ligand binding, two T $\beta R I I s$ and two TRRIs form a heteromeric complex, which transduces intracellular signals by phosphorylating receptor-regulated Smads (R-Smads): Smad2 and Smad3 for TGF- $\beta$ signaling and Smad1 and Smad5 for BMP signaling. These phosphorylated R-Smads form heteromeric Smad complexes with the common-partner Smad Smad4. R-Smad and common-partner Smad complexes associate with various transcription factors and transcriptional co-activators or co-repressors in the nucleus, thereby regulating transcription of a wide spectrum of target genes. TGF- $\beta$ also activates non-Smad pathways, including various mitogen-activated protein kinase pathways. TGF- $\beta$ inhibits epithelial cell proliferation through the induction of $\mathrm{p} 15^{\mathrm{INK} 4 \mathrm{~B}}$ and $\mathrm{p} 21^{\mathrm{CIP} 1 / \mathrm{WAF} 1}$ or through the reduction or c-Myc; therefore, TGF- $\beta$ signaling pathways have tumorsuppressive function during cancer progression. Accordingly, perturbation of TGF- $\beta$ signaling is thought to be involved in many types of cancers. Alterations of genes encoding T $\beta R I I, T \beta R I$, Smad4, and Smad2 have been reported to be responsible for progression of various types of cancers. ${ }^{13}$

Pancreatic cancer is one of the most aggressive cancers and is most commonly diagnosed when it is already at an advanced stage of either metastatic or locally advanced cancer. For the past 40 years, the 5-year survival rate of pancreatic cancer patients has remained only $6 \%$. It appears that lesions occurring in the pancreatic ducts, pancreatic intraepithelial neoplasia (PanIN), are a precursor of pancreatic ductal adenocarcinoma. Numerous studies of PanIN and associated adenocarcinomas have identified common mutation patterns, particularly in KRAS and CDKN2A (encoding $\mathrm{p} 16^{\mathrm{INK} 4 \mathrm{~A}}$ ). Coincident lesions also reportedly show similar patterns of loss of heterozygosity at chromosomes $9 \mathrm{q}, 17 \mathrm{p}$, and $18 \mathrm{q}$, which harbor $C D K N 2 A, T P 53$, and SMAD4, respectively, with studies consistently showing an increasing number of gene alterations in higher grade PanINs. ${ }^{14}$ Blackford et al ${ }^{15}$ suggested that inactivation of the SMAD4 gene correlates with metastasis and poor prognosis in patients with surgically resected pancreatic ductal adenocarcinoma.

We present evidence that TGF- $\beta$ negatively regulates ALDH1 expression in pancreatic cancer cells in a Smaddependent manner and that TGF- $\beta$ in turn impairs the activity of pancreatic CICs. Our model predicts that this regulatory mechanism might be disrupted by mutations and deletions that occur in SMAD4 in human pancreatic cancer cells.

\section{Materials and Methods}

\section{Cell Culture and Reagents}

Human pancreatic adenocarcinoma Panc-1 and BxPC-3 cells were cultured as described previously. ${ }^{16,17}$ Human pancreatic adenocarcinoma SUIT-2 cells were cultured in Dulbecco's modified Eagle's medium containing 10\% fetal bovine serum, $100 \mathrm{U} / \mathrm{mL}$ of penicillin, and 100 $\mu \mathrm{g} / \mathrm{mL}$ of streptomycin. Cells were grown in a $5 \% \mathrm{CO}_{2}$ atmosphere at $37^{\circ} \mathrm{C}$. All experiments were performed on heterogenous populations of shRNA-transfected or adenovirus-infected cells. Among three TGF- $\beta$ isoforms, TGF- $\beta 3$ (R\&D Systems, Minneapolis, MN) was used in this study. Recombinant BMP-4 was purchased from R\&D Systems.

\section{ShRNA}

Lentivirus vectors carrying shRNA were generated as described previously. ${ }^{18}$ pENTR4-H1 was used to insert shRNA specific for human SMAD4 and ALDHIAl into the lentivirus vectors CSII-RfA-CG and CS-RfA, respectively. Vectors were also generated using control shRNA. The sequences of shRNAs are listed in Table 1. Lentiviruses were concentrated using Lenti-X Concentrator (Clontech, Mountain View, CA).

\section{Transfection}

Transient transfection of Smad4 was performed using FuGENE 6 (Roche Diagnostics, Basel, Switzerland) following the manufacturer's instructions. In a 6-well plate, BxPC-3 cells were transfected with $5 \mu \mathrm{g}$ of control vector or pcDNA3-Smad4 in the presence of $6 \mu \mathrm{L}$ of FuGENE 6 per well. Knockdown of Smad4 using siRNA was performed as described previously. ${ }^{19}$ The siRNA sequence targeting human SMAD4 was 5'-UUACAUUCCAACUGCACACCUUUGC- $3^{\prime}$. Panc- 1 cells were transfected with $100 \mathrm{nmol} /$ $\mathrm{L}$ of either siRNA or control siRNA in the presence of $5 \mu \mathrm{L}$ of Lipofectamine 2000 (Invitrogen, Carlsbad, CA) per well of a 6-well plate.

\section{RNA Isolation and RT-PCR}

Total RNA was extracted using Isogen reagent (Nippon Gene, Toyama, Japan). Same cDNA was prepared from each cell, subjected to quantitative real-time RT-PCR analysis. ${ }^{20}$ All samples were run in duplicate. Values were normalized by hypoxanthine guanine phosphoribosyl transferase $1 \mathrm{mRNA}$. The primers for quantitative real-time RT-PCR are listed in Table 1.

\section{Immunoblotting}

Immunoblotting was performed as described previously. ${ }^{20}$ Anti-phospho-retinoblastoma protein (Ser 807/811) antibody 
Table 1 Sequences of Oligonucleotides Used for Generation of shRNAs and Primers in RT-PCR

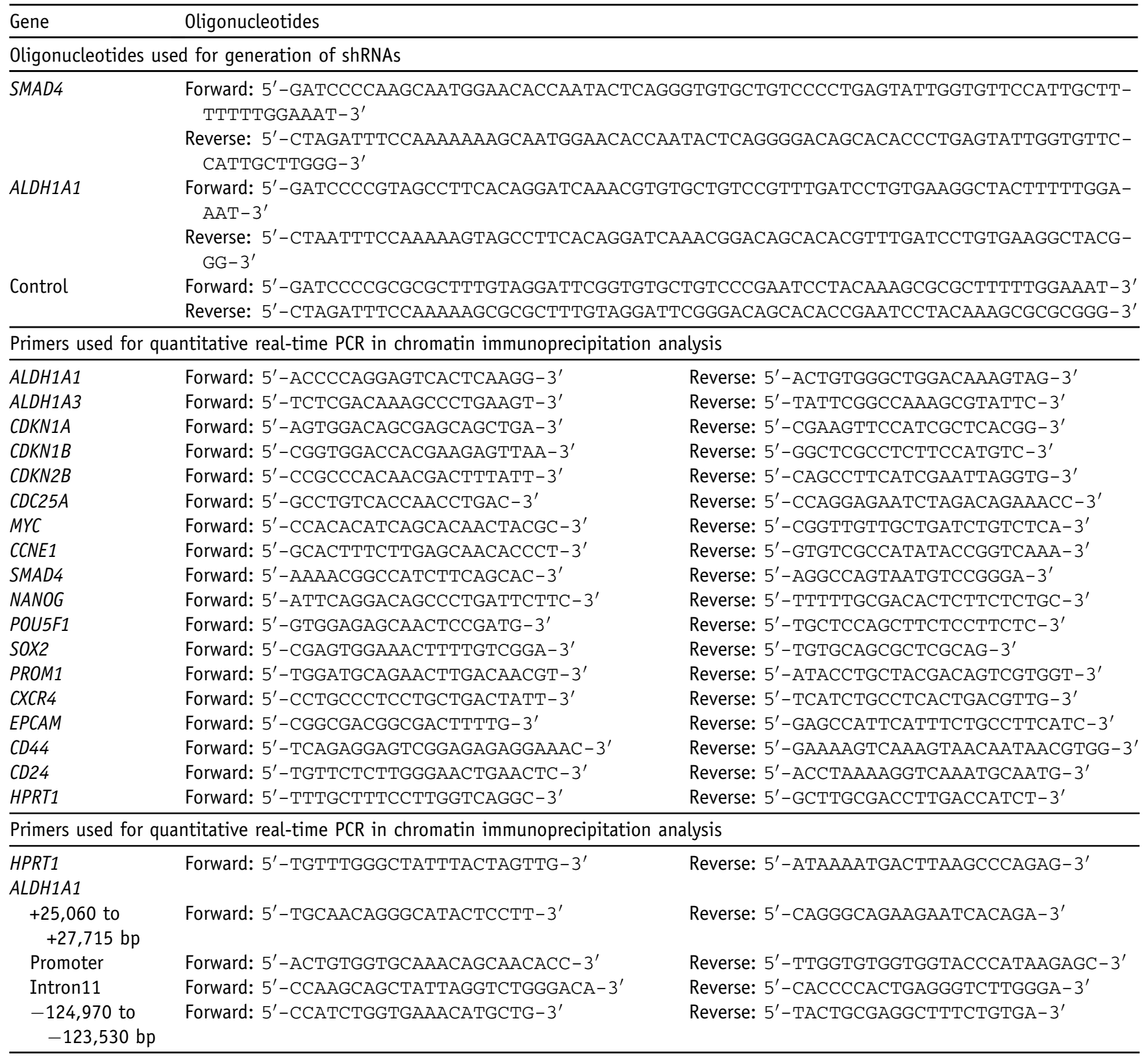

and anti-poly (ADP-ribose) polymerase antibody were purchased from Cell Signaling Technology (Beverly, MA). Anti-ALDH1 antibody was purchased from BD Biosciences (San Jose, CA), and anti-Smad4 antibody was from Santa Cruz Biotechnology (Santa Cruz, CA). Anti- $\alpha-$ tubulin antibody was purchased from Sigma-Aldrich (St Louis, MO).

\section{Cell Proliferation Assay}

Cells from each cell stock were seeded in triplicate in 6-well plates $\left(1 \times 10^{4}\right.$ cells per well $)$. At the indicated days after preparation, cells were counted using a hemocytometer as described previously. ${ }^{20}$

\section{Colony Formation Assay}

The colony formation assay was performed as described previously. ${ }^{21}$ Cells were seeded in $0.3 \%$ agar at $1 \times 10^{4}$ cells per well and cultured for 2 weeks. Diethylaminobenzaldehyde (DEAB) (100 mmol/L; Sigma-Aldrich) was diluted in ethanol and added to the medium of each well at a concentration of 100 $\mu \mathrm{mol} / \mathrm{L}$ every 3 days. The colony diameters were measured using Cellsens Standard (Olympus, Tokyo, Japan).

\section{ChIP Analysis}

Chromatin immunoprecipitation (ChIP) analysis was performed as described previously. ${ }^{22}$ Anti-Smad4 antibody 
(R\&D Systems) and anti-Smad2/3 antibody (BD Biosciences) were used for immunoprecipitation. ${ }^{23}$ Genomic DNA eluted in $100 \mu \mathrm{L}$ of Tris-EDTA buffer was used for quantitative real-time RT-PCR. The primers for quantitative real-time RT-PCR in ChIP analysis are listed in Table 1.

\section{Reporter Assay}

The upstream region $(-25,060$ to $-27,715 \mathrm{bp})$ and downstream region $(+124,970$ to $+123,530 \mathrm{bp})$ of human ALDH1Al were subcloned into the promoter-reporter construct pGL4.10 luc2 (Promega, Madison, WI). Panc1 cells were seeded in a 24 -well plate $\left(5 \times 10^{4}\right.$ cells per well) and transfected with promoter-reporter constructs using FuGENE 6, following the manufacturer's instructions. Twenty-four hours later, cells were treated with TGF- $\beta 3$ for an additional 24 hours and then lyzed. Luciferase activity was measured with the Dual Luciferase Reporter Assay System (Promega) using Mithras LB 940 (Berthold Technologies, Oak Ridge, TN). Luciferase activity was normalized to that of pGL4.10-TK-hRluc, which was co-transfected.

\section{Aldefluor Assay}

Aldefluor assay was performed using the ALDEFLUOR Kit (StemCell Technologies, Vancouver, BC, Canada) as described previously. ${ }^{10}$ MoFlo Astrios (Beckman Coulter, Pasadena, CA) was used for cell sorting, and an Epics-XL flow cytometer (Beckman Coulter) was used for analysis.

\section{Subcutaneous Xenograft Models}

Male BALB/c nu/nu mice (4 weeks of age) were purchased from the Oriental Yeast Company (Tokyo, Japan). The same stocks of cells were prepared, a total volume of $100 \mu \mathrm{L}$ of cells in Matrigel (BD Biosciences) was subcutaneously injected into the left flank of each mouse, and tumors were measured as described previously. ${ }^{24}$ All animal experiments were performed in accordance with the policies of the Animal Ethics Committee at The University of Tokyo.

\section{Immunohistochemistry}

Formalin-fixed, paraffin-embedded pancreatic tissues were obtained from patients with pancreatic adenocarcinoma at The University of Tokyo Hospital. All patients gave their informed consent. Hematoxylin and eosin staining of tissues, antigen retrieval, and immunodetection were performed as described previously. ${ }^{25}$ Anti-Smad4 antibody (Santa Cruz Biotechnology) and anti-ALDH1 antibody (BD Biosciences) were the primary antibodies used for section immunostaining. All studies were conducted using protocols approved by
A

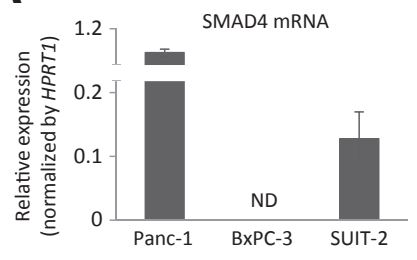

B
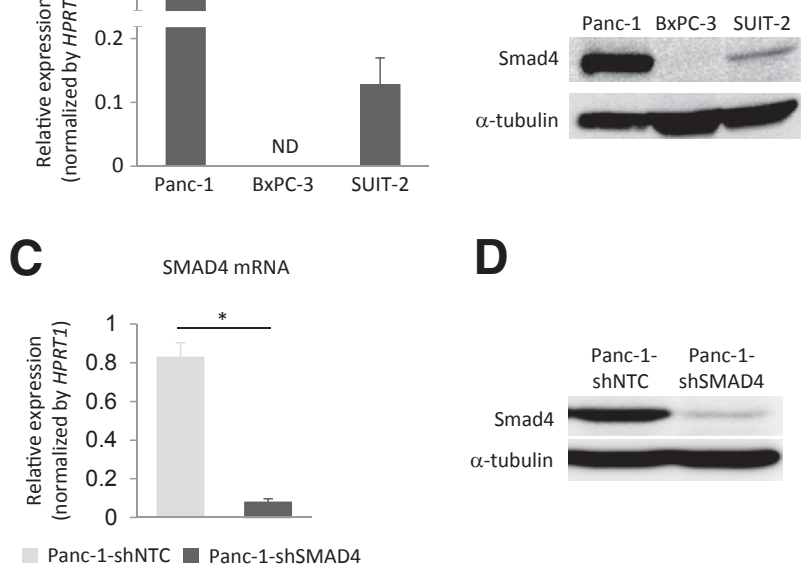

D

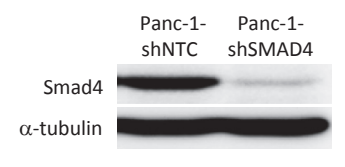

E

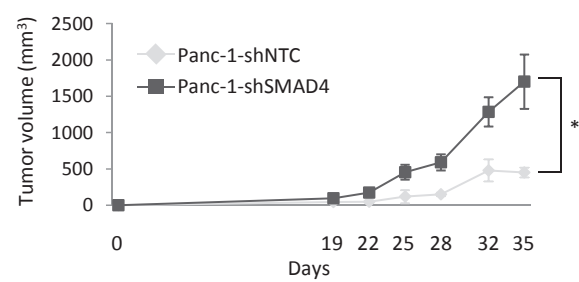

$\mathbf{F}$

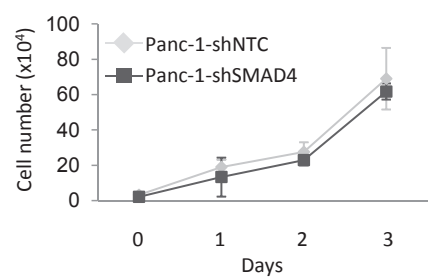

Figure 1 Smad4 is essential for the in vivo pancreatic tumor growth. A: SMAD4 mRNA expression in pancreatic cancer cells was determined by quantitative real-time RT-PCR. B: Cell lysates were immunoblotted with the indicated antibodies. C: Human pancreatic adenocarcinoma Panc-1 cells were infected with lentiviruses carrying control shRNA (Panc-1shNTC) or shRNA targeting SMAD4 (Panc-1-shSMAD4). SMAD4 mRNA expression in these cells was determined by quantitative real-time RTPCR. D: Cell lysates were immunoblotted with the indicated antibodies. E: BALB/c nu/nu mice were subcutaneously injected with Panc-1-shNTC $(n=4)$ and Panc-1-shSMAD4 cells $(n=5)$, and tumor volume was measured. F: The numbers of Panc-1-shNTC and Panc-1-shSMAD4 cells were counted at 1,2 , and 3 days after seeding. Data are presented as means \pm SD. ${ }^{*} P<0.05$. ND, not detected.

Research Ethics Committee at The University of Tokyo, Graduate School of Medicine.

\section{Statistical Analysis}

Two-sided Student's $t$-test was used for examining differences in gene expression levels, tumorigenic potentials, and in vitro proliferative ability in multiple groups. Repeatedmeasures analysis of variance was used for examining 

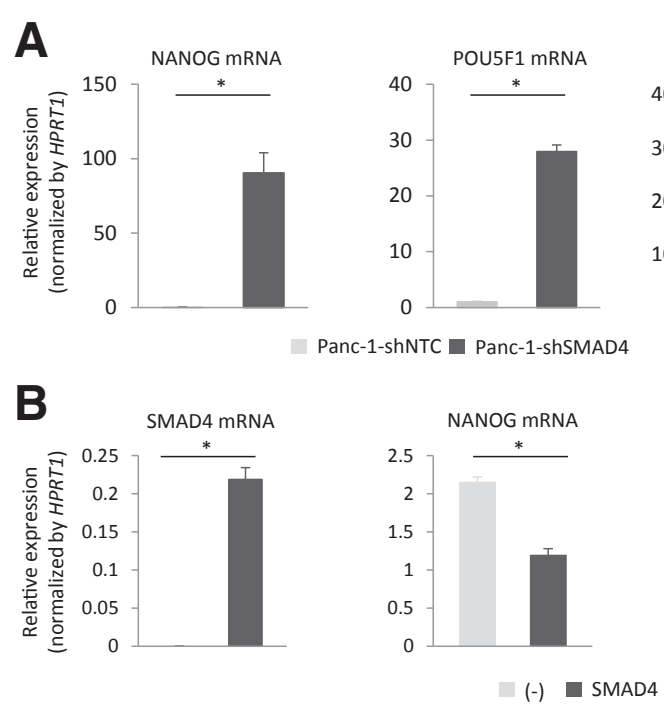

differences in the size of tumors. $P<0.05$ was considered significant.

\section{Results}

\section{Knockdown of SMAD4 in Pancreatic Cancer Cells Leads to Enrichment of CICs}

SMAD4 is frequently mutated in pancreatic cancer cells. We examined Smad4 expression in three human pancreatic cancer cells: Panc-1, BxPC-3, and SUIT-2. Consistent with a previous report, ${ }^{26}$ quantitative real-time RT-PCR analysis and immunoblotting revealed that SMAD4 mRNA and Smad4 protein were expressed in Panc-1 and SUIT-2 cells but remained undetected in BxPC-3 cells (Figure 1, A and B). On the basis of these findings, Panc-1 and SUIT-2 cells were used as Smad4expressing pancreatic cancer cells in this study.

To determine the role of Smad4 expression in tumorigenesis of pancreatic cancer cells in vivo, we established Panc-1 cells with knockdown of Smad4 using shRNA. SMAD4 mRNA and its protein were successfully silenced in cells introduced with shRNA targeting SMAD4 (Panc-1shSMAD4 cells) but not in control cells (Panc-1-shNTC cells) (Figure 1, C and D). These cells were then xenografted into nude mice, and tumorigenic potential was monitored (Figure 1E). Tumors generated by Panc-1shSMAD4 cells were larger than those by Panc-1-shNTC cells, suggesting that Smad4 plays a tumor suppressive role in the formation of pancreatic cancer in vivo.

It is assumed that rapid cell growth is critical for the tumor-forming ability of cancer cells; thus, we assessed the proliferation of these cancer cells in vitro (Figure $1 \mathrm{~F}$ ). Panc-1-shSMAD4 and Panc-1-shNTC cells exhibited similar in vitro proliferation rates. Smad4 knockdown did not alter the expression levels of cyclin-dependent kinase (CDK) regulators (CDKN1A, CDKN1B, CDKN2B, $C C N E 1, M Y C$, and $C D C 25 A$ ) or phosphorylation of retinoblastoma proteins, suggesting that Smad4 did not influence cell cycle progression of pancreatic cancer cells (Supplemental Figure S1, A and B). Moreover, poly (ADPribose) polymerase cleavage, which is an indicator of apoptotic cell death, was not enhanced in Panc-1-shSMAD4 cells (Supplemental Figure S1C).

These results suggested that Panc-1-shSMAD4 cells have high tumorigenic activity despite the fact that proliferative activity does not differ between Panc-1shSMAD4 cells and Panc-1-shNTC cells. In xenograft models, many factors have been implicated in tumor growth, including anchorage-independent growth, escape from various apoptotic stimuli, and interactions between cancer cells and tumor microenvironment. In addition to these mechanisms, we postulated that heterogeneity of pancreatic cancer cells might be altered by the expression of Smad4. Thus, we examined whether certain population of cancer cells (eg, CICs) were enriched in pancreatic cancer cells on knockdown of SMAD4. It is thought that the specific expressions of transcription factors Nanog and Oct 4 are important for the characteristics of pancreatic CICs. ${ }^{27}$ Smad4 silencing in Panc-1 cells elevated the expressions of these pluripotent stem cell markers, including NANOG, POUF5F1 (encoding Oct4 protein), and SOX2 (Figure 2A). On the other hand, forced expression of Smad4 in BxPC-3 cells uniformly decreased the expression levels of these markers (Figure 2B). These results support the hypothesis that $\mathrm{Smad} 4$ expression may negatively regulate the number of CICs in pancreatic cancer cells.

\section{ALDH1 Expression Inversely Correlates with Smad4 Expression in Human Pancreatic Cancer}

To isolate the CIC population in pancreatic cancer cells, we investigated the expression levels of markers that were highly expressed in pancreatic cancer cells with knockdown 


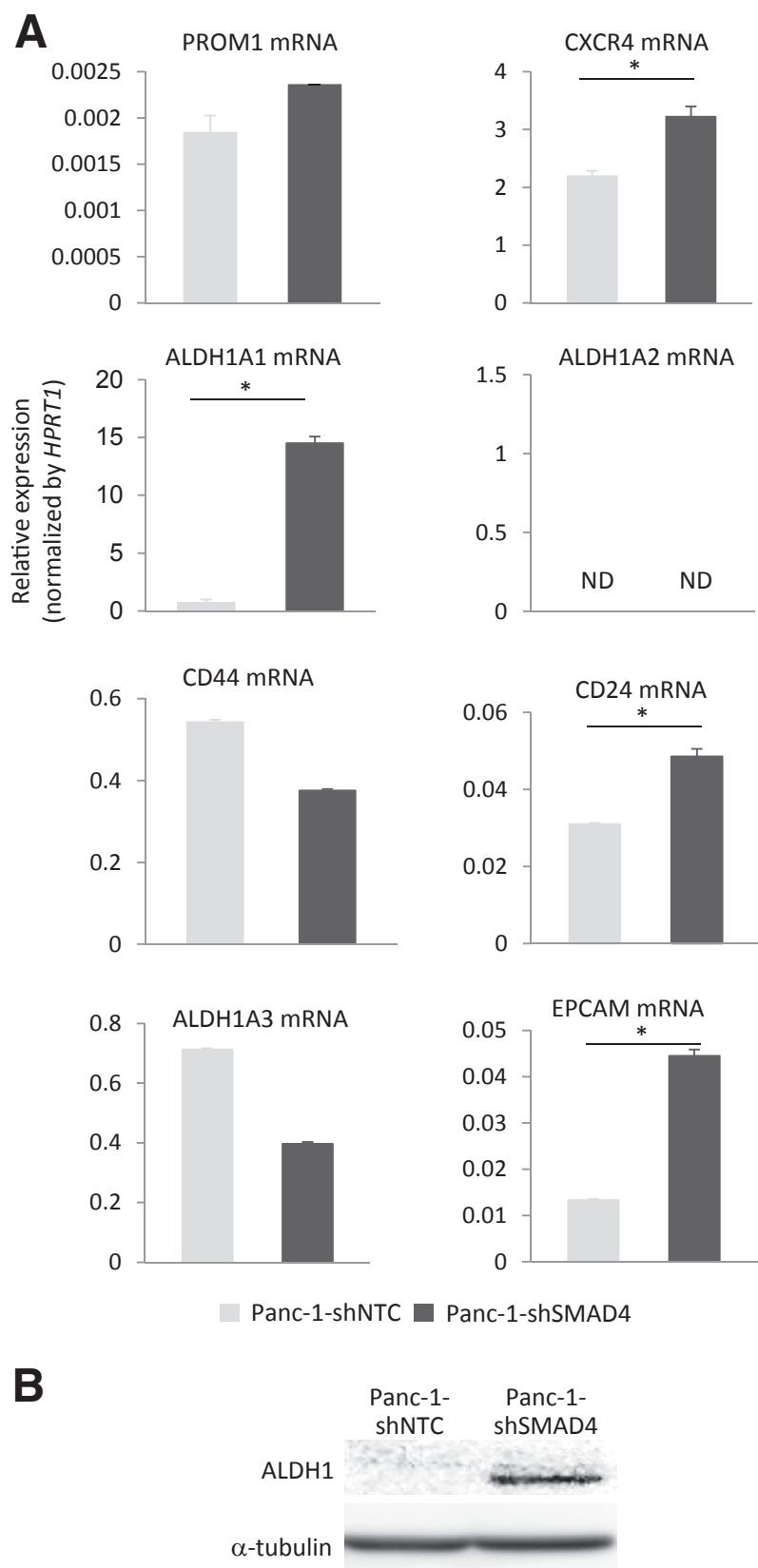

Figure 3 Knockdown of SMAD4 in pancreatic cancer cells leads to increased expression of ALDH1. A: Expressions of cancer-initiating cell markers in Panc-1shNTC cells and Panc-1-shSMAD4 cells was determined by quantitative real-time RT-PCR. B: Cell lysates were immunoblotted with the indicated antibodies. Data are presented as means $\pm \mathrm{SD}$. ${ }^{*} P<0.05$. ND, not detected.

of SMAD4. CD133 (alias PROM1), CD44, CD24, epithelial specific antigen (alias epithelial cell adhesion molecule), and CXCR4 are reportedly useful for isolation of pancreatic CICs. ${ }^{28-30}$ ALDH1 activity is also reported to be able to identify CICs in pancreatic cancers. ${ }^{31}$ Quantitative real-time RT-PCR analysis revealed much higher expression of ALDH1A1 mRNA in Panc-1-shSMAD4 cells than in control Panc-1-shNTC cells (Figure 3A). The amounts of ALDH1 protein were also remarkably up-regulated in Panc1-shSMAD4 cells (Figure 3B). Because other ALDH1 isoforms are reportedly expressed in certain types of $\mathrm{CICs},{ }^{32}$ their expressions in Panc- 1 cells were also examined (Figure 3A). ALDH1A2 mRNA was not detected in these cells. Expression of ALDH1A3 mRNA was suppressed in Panc-1-shSMAD4 cells, implying that this gene was not important for pancreatic CIC identification. Together, these findings suggested that ALDH1A1expressing pancreatic cancer cells were enriched in cancer cells with SMAD4 knockdown.

Next, we used Aldefluor assay to detect the cell population that possessed high ALDH1 enzymatic activity among these pancreatic cancer cells (Figure 4A). This assay specifically distinguished cells with high enzymatic activity from those with low activity by using DEAB, which inhibits the function of all members of the ALDH family. Cells with high ALDH activity were regarded as having high ALDH1A1 activity $\left(\mathrm{ALDH} 1^{\mathrm{hi}}\right.$ cells) in this study. These ALDH1 $1^{\text {hi }}$ cells comprised $3 \%$ to $10 \%$ of the pancreatic cancer cells (Figure 4A). Next, we examined the correlation between Smad4 expression and ALDH1 activity in Panc1 cells. siRNA targeting SMAD4 was introduced into Panc-1 cells, and Aldefluor assay was conducted (Figure 4, B and C). The introduction of siRNA targeting SMAD4 increased both ALDH1A1 expression and ALDH1 enzymatic activity in these cells.

We then profiled the expression patterns of the Smad4 and ALDH1 proteins in clinical samples from patients with pancreatic cancer. In 16 tissue samples of moderately differentiated adenocarcinoma, immunohistochemical analysis using anti-Smad4 antibody revealed two groups: tissues containing Smad4-expressing cancer cells at a low frequency and tissues exhibiting a high frequency of these cells (Figure 5). In both tissue types, intense ALDH1 staining was detected mainly in cells expressing low levels of Smad4, and Smad4 was also mainly observed in cells that did not show intense ALDH1 staining, with few exceptions. Overall, Smad4 expression was inversely correlated with that of ALDH1 in cancer cells within some human pancreatic cancer tissues (Table 2). These results support the possibility that ALDH1 expression in pancreatic cancer cells was suppressed by Smad4-mediated signal transduction.

\section{ALDH1 Expression Is Essential for the Tumorigenic Ability of Pancreatic Cancer Cells}

To investigate whether ALDH1 served as a marker for pancreatic CICs, ALDH $1^{\text {hi }}$ cells and ALDH1 ${ }^{-}$cells were sorted from pancreatic cancer cells and subjected to further analyses. To assess the differentiation potency of each population, these sorted cells were cultured in vitro for a week and then reanalyzed by flow cytometry (Figure 6A). Among both SUIT-2 cells and Panc-1 cells, only ALDH1 ${ }^{-}$ cells were detected in the cultured $\mathrm{ALDH}^{-}$cells. In contrast, cultured ALDH $1^{\text {hi }}$ cells produced both ALDH $1^{\text {hi }}$ cells and $\mathrm{ALDH} 1^{-}$cells, suggesting that ALDH $1^{\mathrm{hi}}$ cells possessed multiple differentiation potency. In accordance with these findings, pluripotent stem cell markers, including 

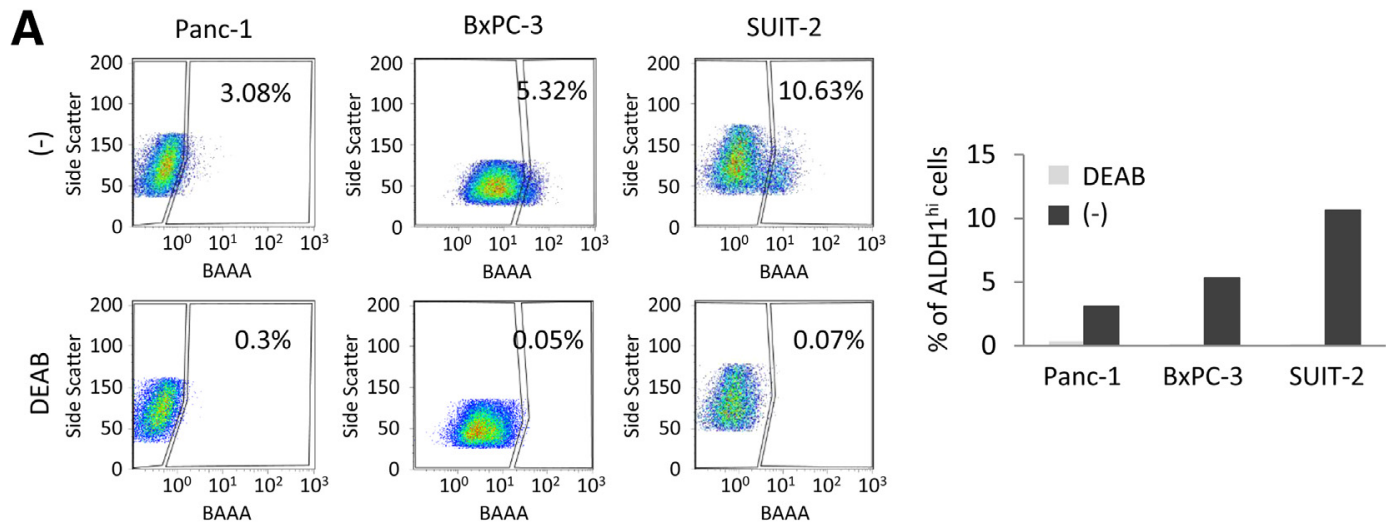

B
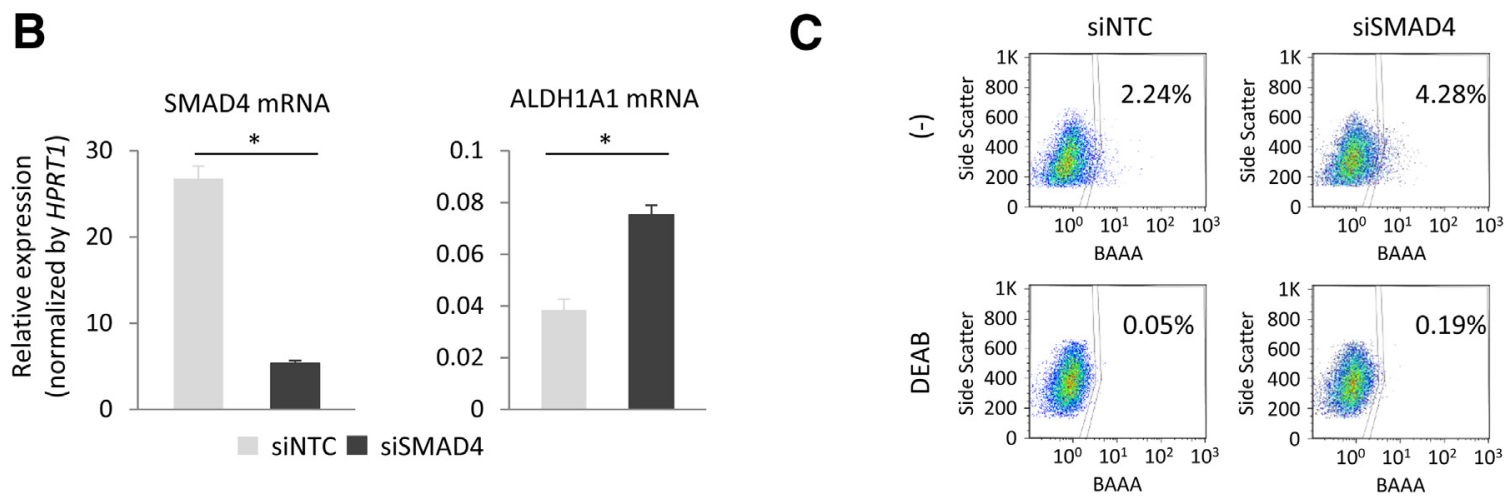

Figure $4 A A^{2}{ }^{h i}$ cells are enriched in pancreatic cancer cells on knockdown of SMAD4. A: Pancreatic cancer cells were treated with BODIPYaminoacetaldehyde (BAAA) in the presence or absence of diethylaminobenzaldehyde (DEAB) for 45 minutes. Then the fraction of $A L D H 1^{\text {hi }}$ cells was analyzed by flow cytometry. The percentage of $A L D H 1{ }^{\text {hi }}$ cells within the total population of viable cells is indicated in the histogram and graph. B: Panc- 1 cells were transfected with control siRNA (siNTC) or siRNA targeting SMAD4 (siSMAD4). Expression levels of SMAD4 and ALDH1A1 mRNA were determined by quantitative real-time RT-PCR. C: The Panc-1 cells in B were treated with BAAA in the presence or absence of DEAB for 45 minutes. Then the fraction of ALDH $1^{\text {hi }}$ cells was analyzed by flow cytometry. The numbers in the histograms show the percentage of ALDH1 ${ }^{\text {hi }}$ cells within the total population of viable cells. Data are presented as means $\pm \mathrm{SD}(\mathbf{B}) .{ }^{*} P<0.05$.

NANOG, POU5F1, and SOX2, were highly expressed in ALDH $1{ }^{\text {hi }}$ pancreatic cancer cells (Supplemental Figure S2), whereas expression of other CIC markers was not elevated (Supplemental Figure S3).

We next investigated the tumor-forming ability of each fraction in vitro and in vivo. The colony formation assay revealed that the ALDH $1^{\text {hi }}$ cells formed larger colonies than ALDH1 ${ }^{-}$cells, which was the case among cells sorted from both the SUIT-2 cells and Panc-1 cells (Figure 6B). Similarly, when equal amounts of ALDH1 ${ }^{\text {hi }}$ cells and ALDH1 ${ }^{-}$cells sorted from SUIT- 2 cells were xenografted into nude mice, large tumors were observed in mice bearing ALDH $1{ }^{\text {hi }}$ cells (Figure 6C). To directly compare the tumor-forming abilities of $A L D H 1{ }^{\text {hi }}$ and ALDH1 ${ }^{-}$cells, various amounts of each population were subcutaneously xenografted (Table 3). Tumor formation from $A L D H 1^{\text {hi }}$ cells required injection of 100 cells, whereas injection of $100 \mathrm{ALDH}^{-}$cells failed to form tumors in all mice examined. These observations suggested that the ALDH $1{ }^{\text {hi }}$ cells within pancreatic cancer cells included a greater proportion of CICs than the ALDH1 ${ }^{-}$cells.

We then examined whether ALDH1 expression was essential for the tumorigenic properties of CICs. Panc-1 cells stably containing shRNA targeting ALDHIAl (Panc1-shALDH1A1) were established. The shRNA specifically knocked down the expression of ALDH1A1 mRNA without affecting that of ALDH1A3 mRNA (Figure 7A). Aldefluor assay revealed that ALDH1 activity was completely abolished in Panc-1-shALDH1A1 cells (Figure 7B). Cell proliferation did not differ between Panc1-shALDH1A1 cells and control cells (Panc-1-shNTC) (Figure 7C); however, Panc-1-shALDH1A1 cells exhibited decreased colony-forming ability compared with Panc-1shNTC cells, which could mimic the inhibitory effect of TGF- $\beta$ on tumor formation (Figure 7D). Moreover, pharmacologic inhibition of ALDH1 activity by DEAB potently reduced the colony-forming ability of parental Panc-1 cells (Figure 7D). Thus, we postulated that ALDH1 serves as a marker for pancreatic CICs, and that enzymatic ALDH1 activity is crucial for the tumorigenic potential of pancreatic CICs.

Smad4 Negatively Regulates ALDH1A1 Transcription in Pancreatic Cancer Cells in a TGF- $\beta$-Dependent Manner

Smad4 forms hetero-oligomeric complexes with the R-Smads (ie, Smad 2 and Smad3 for TGF- $\beta$ signaling and 


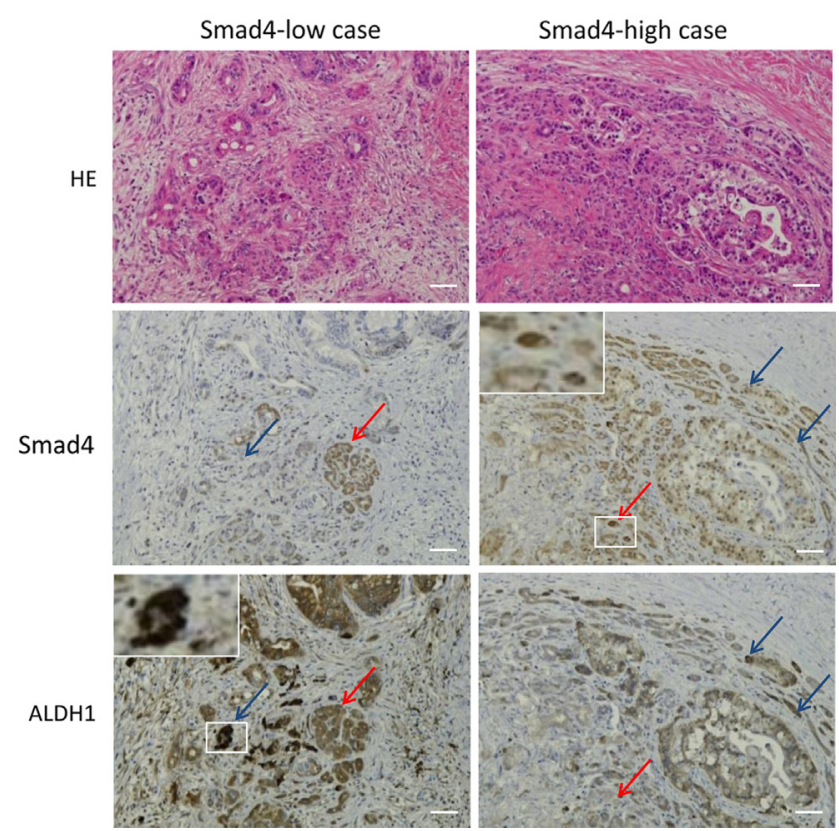

Figure 5 ALDH1 is expressed in cells expressing low levels of Smad4 in human pancreatic cancer. Moderately differentiated adenocarcinoma tissues, specifically from the invasive front $(n=8)$ and center region $(n=8)$, from pancreatic tumor patients were stained with hematoxylin and eosin (H\&E), anti-Smad4 antibody, and anti-ALDH1 antibody. Representative images of immunohistochemical analyses and H\&E staining of tissues are shown. Smad4-expressing cancer cells and ALDH1-expressing cancer cells are also indicated (inner frame). Lesion sites were classified based on whether they contained a low or high density of Smad4expressing cancer cells. Red arrows indicate high Smad4-expressing cancer cells, and blue arrows indicate low Smad4-expressing cancer cells. The boxed regions correspond to the insets at higher magnification $(\times 400)$. Scale bar $=30 \mu \mathrm{m}$.

Smad1 and Smad5 for BMP signaling) and transduces specific signals. To identify which signals were involved in regulating ALDH1 expression in pancreatic cancer cells, SUIT-2 cells and Panc-1 cells were exogenously stimulated with TGF- $\beta$ and BMP-4 (Figure 8 , A and B). TGF- $\beta$ inhibited the transcription of ALDH1A1 mRNA in both SUIT-2 cells and Panc-1 cells immediately, which in turn reduced ALDH1 protein translation. In contrast, BMP4-induced modest reduction of ALDH1A1 mRNA was observed only in SUIT-2 cells but not in Panc-1 cells. BMP-4 reduced ALDH1 protein in neither SUIT-2 nor Panc-1 cells. In both SUIT- 2 cells and Panc-1 cells, ALDH1 activity was inhibited by TGF- $\beta$ and less potently by BMP-4 (Figure 8C). These results suggested that ALDH1 regulation by Smad4 in pancreatic cancer cells was dependent mainly on TGF- $\beta$ signaling. These findings also predict that TGF- $\beta$ may attenuate the tumorigenic potentials of pancreatic cancer cells through the reduction of ALDH1 expression. Accordingly, TGF- $\beta$ strongly inhibited colony formation of both SUIT-2 cells and Panc-1 cells, and BMP-4 was less potent than TGF- $\beta$ (Figure 8D).

Finally, we performed biochemical experiments aiming to uncover the molecular mechanism of transcriptional regulation of ALDH1A1 mRNA by Smad-dependent TGF$\beta$ signaling. Because TGF- $\beta$ down-regulated ALDH1A1 mRNA expression even after 24 hours stimulation, it was expected that $A L D H 1 A 1$ was a direct target of the Smad pathway (Figure 8A). Our previous ChIP and ChIPsequencing analysis of human diffuse-type gastric cancer cells, OCUM-2MLN, ${ }^{21}$ predicted four loci around the ALDHIAl locus to be candidate Smad-binding sites: upstream region $(-25,060$ to $-27,715 \mathrm{bp})$, promoter, intron 11 , and downstream region $(+124,970$ to $+123,530 \mathrm{bp})$ (unpublished data). We performed a new ChIP analysis to ascertain whether direct Smad binding to the ALDHIAl genome was involved in pancreatic cancer cells. ChIP analysis using anti-Smad2/3 antibody revealed Smad2/3 binding in some loci, but the binding profiles differed between SUIT-2 cells and Panc-1 cells (Figure 9A). In contrast, ChIP analysis using anti-Smad4 antibody revealed common binding of Smad4 to the upstream region and the downstream region in both types of cancer cells (Figure 9B). Moreover, these bindings of Smad4 were enhanced by treatment with TGF- $\beta$, suggesting that these sites were important for TGF- $\beta$-Smad-mediated regulation of ALDH1A1 mRNA. Constructs containing these Smad4binding candidate sites were introduced into Panc- 1 cells, and reporter activities were examined in the presence or absence of TGF- $\beta$ (Figure 9C). The reporter activity of the construct that contained the $+124,970$ to $+123,530 \mathrm{bp}$ region was modestly suppressed by TGF- $\beta$. Together, these results suggested that TGF- $\beta$ might negatively regulate ALDHIAl transcription in pancreatic cancer cells through the binding of Smad4 to this region.

\section{Discussion}

There is increasing evidence that small fractions of CICs in tumor tissues may be responsible for recurrence in many cancers. However, little is known about the regulatory mechanisms involved in their maintenance. The present results document the importance of Smad-mediated TGF- $\beta$ signals in the maintenance of $\mathrm{ALDH} 1^{\mathrm{hi}}$ cells within pancreatic cancer.

Table 2 Immunohistochemical Analyses of Moderately Differentiated Adenocarcinoma Tissues Using Anti-Smad4 Antibody and Anti-ALDH1 Antibody

\begin{tabular}{llllll}
\hline & \multicolumn{2}{l}{ Invasive front } & & \multicolumn{2}{l}{ Center } \\
\cline { 2 - 3 } \cline { 5 - 6 } Patient no. & Smad4 & ALDH1 & & Smad4 & ALDH1 \\
\hline 1 & Low & High & Low & High \\
2 & High & High & Low & High \\
3 & High & High & High & High \\
4 & High & Low & Low & High \\
5 & Low & Low & Low & High \\
6 & High & Low & High & Low \\
7 & Low & High & High & Low \\
8 & High & High & High & Low \\
\hline
\end{tabular}


A

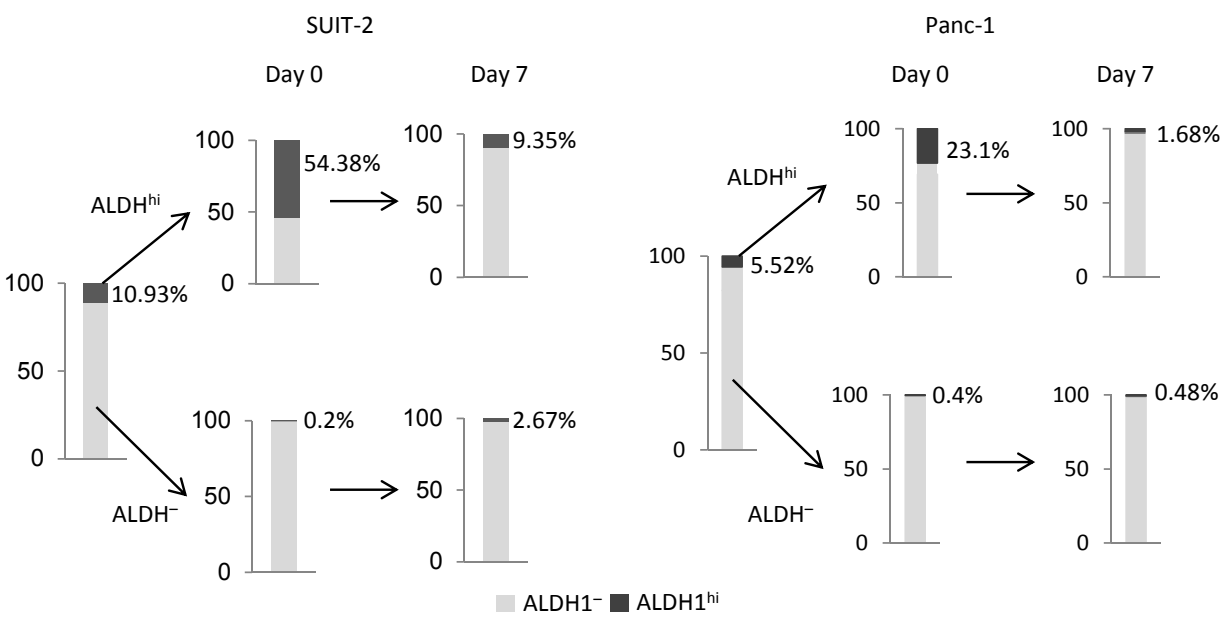

B

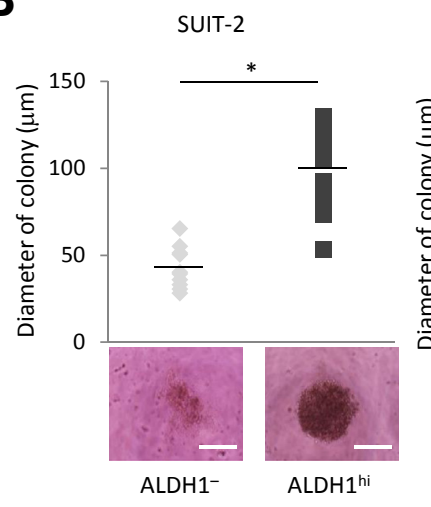

C

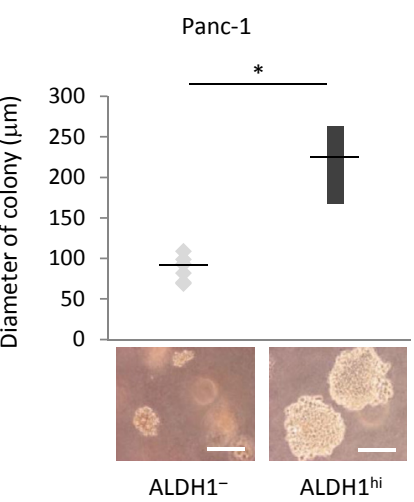

$\mathrm{ALDH}^{\text {hi }}$

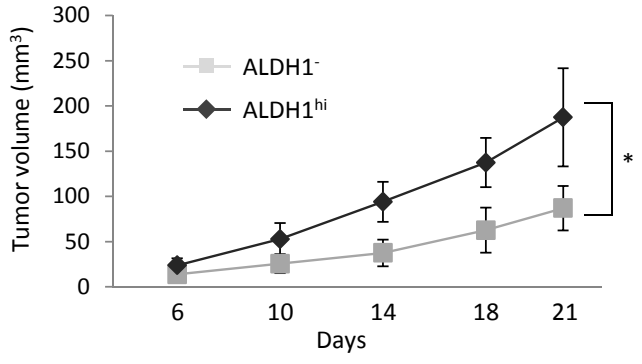

Figure 6 ALDH1 serves as a cancer-initiating cell marker of pancreatic cancer cells. A: ALDH1 $1^{-}$cells and ALDH1 $1^{\text {hi }}$ cells were sorted from human pancreatic adenocarcinoma SUIT-2 and Panc-1 cells using Aldefluor assay. Seven days after fractionation, cells were reanalyzed by flow cytometry. Numbers beside the graphs indicate the percentages of ALDH $1^{\text {hi }}$ cells within the total population of viable cells. B: ALDH1 ${ }^{-}$cells and ALDH $1^{\text {hi }}$ cells from SUIT-2 or Panc- 1 cells were cultured in soft agar for 2 weeks. Colony diameters and representative images are shown. C: BALB/c nu/nu mice were subcutaneously injected with $1 \times 10^{4}$ of ALDH $1^{-}$cells $(n=6)$ and ALDH $1{ }^{\text {hi }}$ cells $(n=4)$ from SUIT-2 cells, and tumor volume was measured. Data are presented as means \pm SD $(\mathbf{B}$ and $\mathbf{C})$. ${ }^{*} P<0.05$. Scale bar $=100 \mu$ m.

\section{The Role of Smad4 during Pancreatic Cancer Progression}

During cancer progression, mutations and deletions occur in many types of genes. Among them, SMAD4, a candidate tumor suppressor gene on chromosome 18q21, has high frequencies of allelic losses in many types of tumors. ${ }^{33-35}$ SMAD4 mutations have been found in $17 \%$ to $56 \%$ of patients with juvenile polyposis syndrome and in $22 \%$ to $46 \%$ of patients with advanced colorectal cancers. ${ }^{33,34}$ Takaku et $\mathrm{al}^{36}$ reported polyps phenotypically similar to human juvenile polyps in the stomach and duodenum of Smad4 heterozygous knockout mice. They also observed that intestinal polyps in $\operatorname{Smad4}(+/-) A p c^{\Delta 716}(+/-)$ mice developed into more malignant polyps than those in the simple $A p c^{\Delta 716}(+/-)$ heterozygotes. ${ }^{37}$ These results indicate that Smad4 plays a tumor suppressive role in the malignant progression of these tumors. Bardeesy et $\mathrm{al}^{31}$ addressed the role of Smad4 deficiency in pancreatic cancer in experiments using genetically engineered mice. Although the activated $\operatorname{Kras}^{G 12 D}$ allele alone elicited PanIN, the combination of Kras activation and Smad4 deficiency resulted in the rapid development of tumors that resembled intraductal papillary mucinous neoplasia, a human pancreatic ductal adenocarcinoma precursor. Another in vivo experiment revealed that the absence of Pten initiated widespread premalignant lesions in the pancreas, which were significantly accelerated by Smad 4 deficiency. ${ }^{38}$ These findings indicate that SMAD4 mutations or deletions accelerate the malignant progression of cancer in combination with other gene alterations.

To our knowledge, the present study provides the first evidence that SMAD4 deletion is involved in pancreatic CIC maintenance. ALDH1A1 mRNA expression in

Table 3 Incidences of Tumor Formation of $\mathrm{ALDH}^{-}$Cells and ALDH $1^{\text {hi }}$ Cells from SUIT-2 Cells

\begin{tabular}{lllll}
\hline \multirow{5}{*}{ Cell } & \multicolumn{4}{l}{ Tumor incidence } \\
\cline { 2 - 5 } & 10,000 & 3000 & 1000 & 100 \\
\hline ALDH1 $^{-}$ & $2 / 2$ & $3 / 3$ & $3 / 4$ & $0 / 3$ \\
ALDH1 $^{\text {hi }}$ & $2 / 2$ & $6 / 6$ & $5 / 5$ & $4 / 4$ \\
\hline
\end{tabular}

Incidences of tumor formation of SUIT-2 cells in Figure 6. Tumor formation was determined at 2 months after injection. 

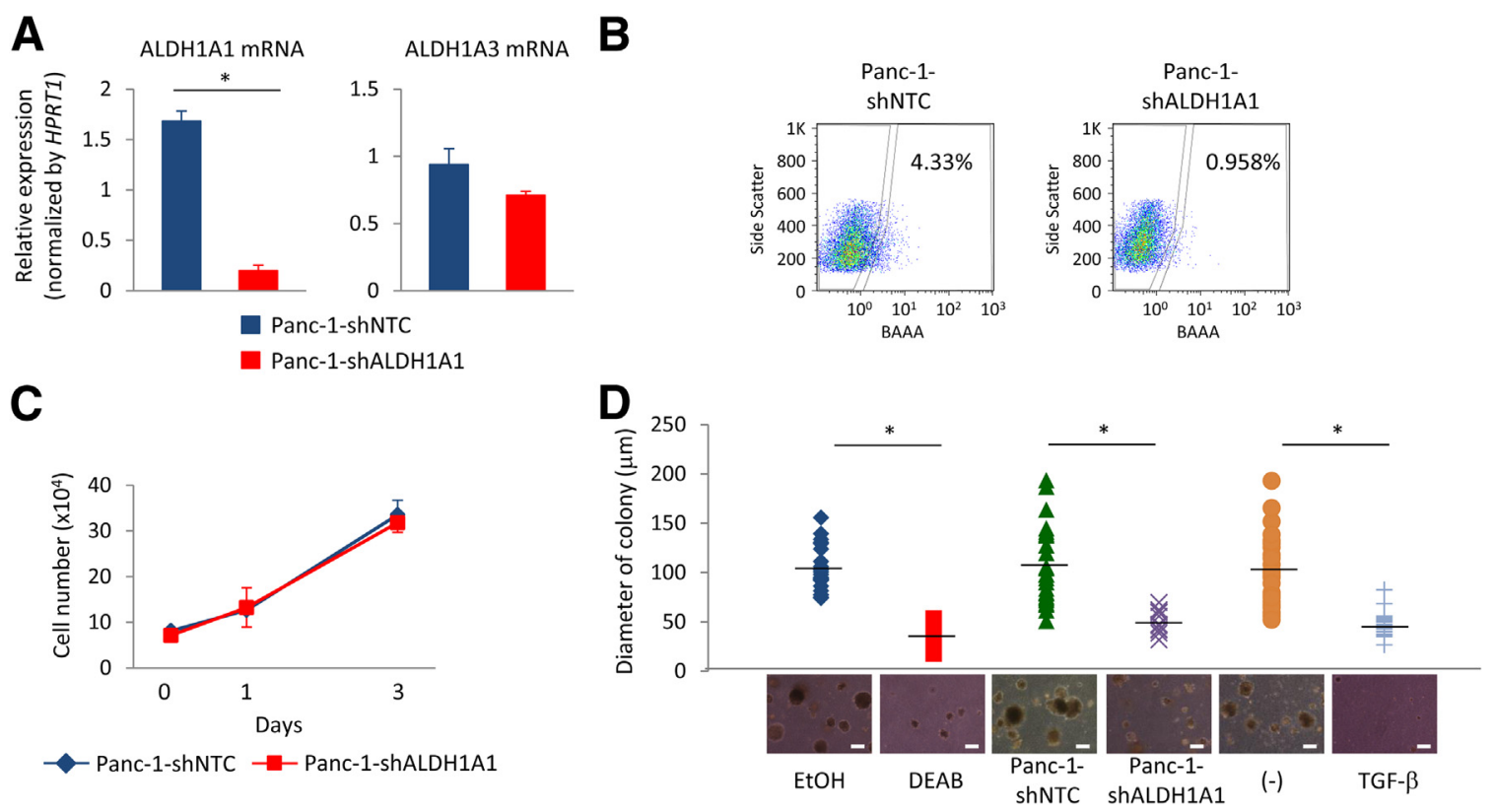

Figure 7 ALDH1 is important for the tumorigenic potential of pancreatic cancer cells. A: Expression levels of ALDH1A1 mRNA and ALDH1A3 mRNA in Panc1-shNTC and Panc-1-shALDH1A1 cells were determined by quantitative real-time RT-PCR. B: Panc-1-shNTC and Panc-1-shALDH1A1 cells were treated with BODIPY-aminoacetaldehyde (BAAA) in the presence or absence of diethylaminobenzaldehyde (DEAB) for 45 minutes. Then the fraction of ALDH1 ${ }^{\text {hi }}$ cells was analyzed by flow cytometry. The numbers in the histograms show the percentage of ALDH1 ${ }^{\text {hi }}$ cells within the total population of viable cells. C: The numbers of Panc-1-shNTC and Panc-1-shALDH1A1 cells were counted at 1 and 3 days after seeding. D: Panc-1-shNTC and Panc-1-shALDH1A1 cells were cultured in soft agar for two weeks. Untreated Panc-1 cells and cells treated every 2 days with $3 \mu \mathrm{L}$ of ethanol (EtOH), $100 \mu \mathrm{mol} / \mathrm{L} \mathrm{DEAB}$, or $1 \mathrm{ng} / \mathrm{mL}$ of transforming growth factor (TGF)- $\beta 3$ were also prepared. Colony diameters and representative images are shown. Data are presented as means \pm SD. ${ }^{*} P<0.05$. Scale bar $=100 \mu \mathrm{m}$.

pancreatic cancer cells was up-regulated by silencing of Smad4, which in turn increased the population of ALDH $1^{\text {hi }}$ tumorigenic cancer cells (Figures 3, A and B, and Figure 4, $\mathrm{B}$ and $\mathrm{C})$. This concept was further reinforced by our examination of clinical specimens. In human pancreatic cancer tissues, Smad4 protein expression levels were inversely correlated with those of ALDH1 protein (Figure 5 and Table 2). These observations suggested that disruption of Smad4-mediated TGF- $\beta$ signaling is important for pancreatic CIC regulation.

Duda et $\mathrm{al}^{39}$ reported that restoration of Smad4 into SMAD4 homozygous-deleted human pancreatic tumor cells reduced in vivo tumorigenesis. They also documented that expression of vascular endothelial growth factor was down-regulated in Smad4-restored pancreatic cancer cells. Because angiogenesis is thought to provide a favorable vascular niche for CICs, both CIC maintenance and formation of a suitable microenvironment for CICs are likely affected by Smad4 expression in pancreatic cancer cells.

\section{The Role of ALDH1 Expression in Pancreatic CICs}

Recent evidence indicates that specific cell populations of CICs exist in various cancers, which may be identified by specific markers, such as CD133 and CD44, and as a side population by flow cytometry. ${ }^{8,28-30}$ The present study revealed that ALDH1 may be useful for the isolation of pancreatic CICs (Figure 6). We also found that TGF- $\beta$ diminished ALDH $1^{\text {hi }}$ populations of pancreatic cancer cells (Figure 8). CICs are thought to possess properties similar to those of normal stem cells, including the ability to selfrenew while producing differentiated daughter cells. In this study, ALDH $1{ }^{\text {hi }}$ cells within pancreatic cancer cell populations exhibited strong expressions of NANOG, POU5F1 (OCT4A), and SOX2, indicating that ALDH1 ${ }^{\text {hi }}$ pancreatic cancer cells possessed the same characteristics as pluripotent stem cells (Supplemental Figure S2). Expression levels of NANOG, POU5F1, and SOX2 were also increased in Panc-1-shSMAD4 cells (Figure 2A), suggesting that these markers were regulated by Smad4-mediated signaling. However, silencing of ALDH1 in pancreatic cancer cells did not alter the expression levels of these markers (data not shown); thus, NANOG, POU5F1, and SOX2 may be regulated by TGF- $\beta$ in an ALDH1-independent manner. ${ }^{40,41}$

It is now believed that CICs are resistant to conventional treatments, including chemotherapy and irradiation. For example, the ATP-binding cassette (ABC) drug transporters protect CICs from many chemotherapeutic agents. Directly targeting CICs may be crucial for preventing cancer recurrences and metastases. To investigate this issue, Panc-1shALDH1 cells were established and characterized for their tumorigenic potentials. We found that tumor-forming ability was disturbed by ALDH1 silencing (Figure 7). Many previous reports have documented the importance of ALDH1 for the proliferation, differentiation, and metabolism of several 
A

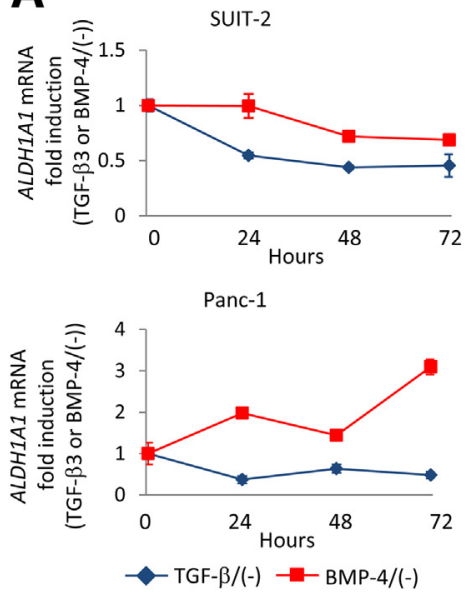

C
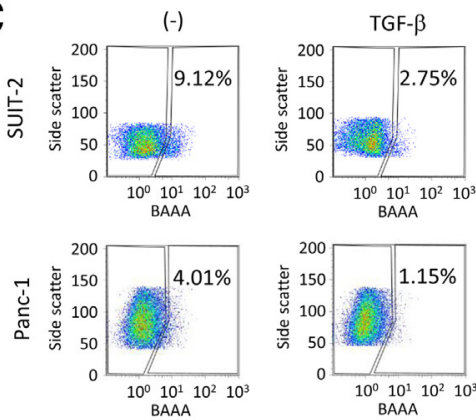

D

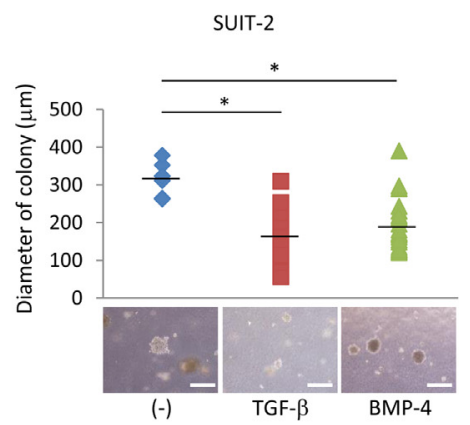

\section{B}

SUIT-2

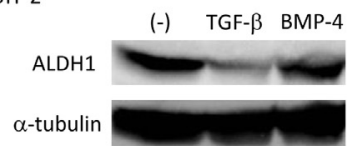

Panc-1
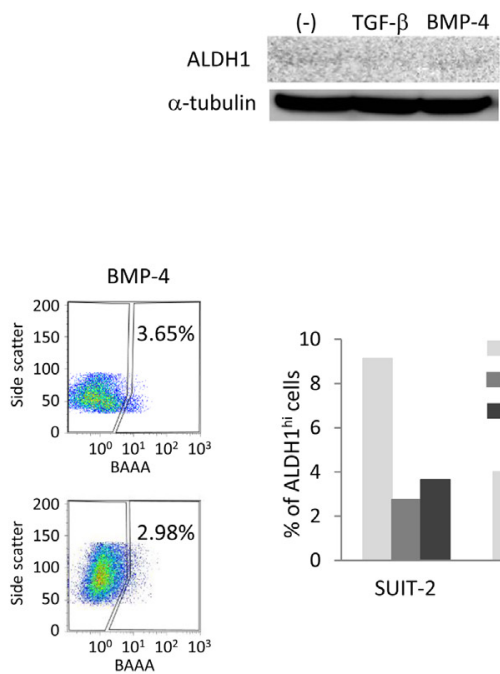
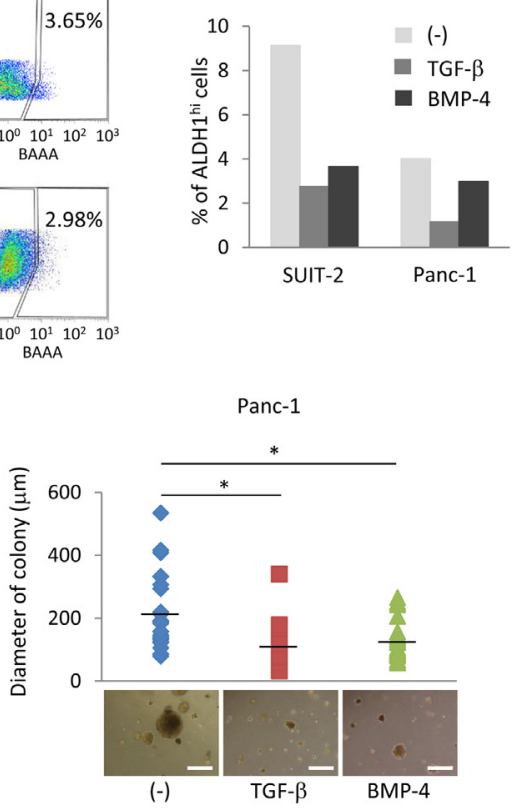

Figure 8 The $A L D H 1^{\text {hi }}$ population within pancreatic cancer cells is diminished by transforming growth factor (TGF) $\beta$ and less potently by bone morphogenetic protein (BMP)-4. A: Human pancreatic adenocarcinoma SUIT-2 and Panc-1 cells were treated with $1 \mathrm{ng} / \mathrm{mL}$ of TGF- $\beta 3$ or 30 $\mathrm{ng} / \mathrm{mL}$ of BMP-4 for the indicated number of hours. ALDH1A1 mRNA expression levels were determined by quantitative real-time RT-PCR. B: SUIT-2 and Panc- 1 cells were treated with $1 \mathrm{ng} / \mathrm{mL}$ of TGF- $\beta 3$ or $30 \mathrm{ng} / \mathrm{mL}$ of BMP- 4 for 48 hours. Cell lysates were immunoblotted with the indicated antibodies. C: SUIT-2 and Panc-1 cells were treated with BODIPY-aminoacetaldehyde (BAAA) in the presence or absence of diethylaminobenzaldehyde for 45 minutes. Then the fraction of the ALDH $1^{\text {hi }}$ cells was analyzed by flow cytometry. The percentages of $\mathrm{ALDH} 1^{\text {hi }}$ cells within the total population of viable cells are indicated in the histograms and graph. D: SUIT-2 and Panc- 1 cells were treated with $1 \mathrm{ng} / \mathrm{mL}$ of TGF- $\beta 3$ or $30 \mathrm{ng} / \mathrm{mL}$ of BMP-4 every 2 days and cultured in soft agar for 2 weeks. Colony diameters and representative images are shown. Data are presented as means \pm SD fold change under TGF- $\beta 3$ or BMP- 4 stimulation (A) and means \pm SD (D). ${ }^{*} P<0.05$. Scale bar $=200 \mu \mathrm{m}$. agents in cells. ${ }^{42-45}$ However, the present results provide the first evidence that ALDH1 expression may directly affect the tumor-forming ability of pancreatic cancer cells. As shown in Figure 7D, pharmacologic inhibition of ALDH1 enzymatic activity using DEAB or related compounds could eradicate the CICs in pancreatic cancer tissue and thus may have a therapeutic benefit in pancreatic cancer treatment.

\section{Biochemical Analysis of the Regulatory Mechanism of ALDH1 Expression by Smad4}

Previous studies have identified several molecular mechanisms that regulate ALDH1 expression. Moreb et $\mathrm{al}^{46}$ found that co-stimulation with interleukin-1 and tumor necrosis factor- $\alpha$ increased the expression of ALDH1 mRNA and its protein in human bone marrow cells. Treatment of human mammary epithelial cells with miR-146a inhibitor also decreases the percentage of ALDH1-positive cells. ${ }^{47}$ Elizondo et $\mathrm{al}^{48}$ proposed a model in which retinoic acid receptor$\alpha$ and CCAAT/enhancer binding protein- $\beta$ activate the $A L D H 1$ gene promoter through the retinoic acid response element and the CCAAT/enhancer binding protein- $\beta$ response element in mouse hepatoma Hepa-1 cells. Furthermore, ALDH1 enzyme expression and activity are reduced by inhibition of the Notch signaling pathway in certain types of mouse osteosarcoma cells. ${ }^{49}$ However, the molecular mechanism behind the transcription of ALDH1A1 mRNA in cancer cells remains unknown. We performed biochemical analyses to examine the regulatory mechanism of TGF$\beta$-mediated expression of ALDH1A1 mRNA in pancreatic cancer cells (Figure 9C). Through these studies, we identified several Smad4-binding sites that might be important for the transcriptional regulation of ALDH1Al (Figure 9). Our results suggested that TGF- $\beta$ negatively regulates the 


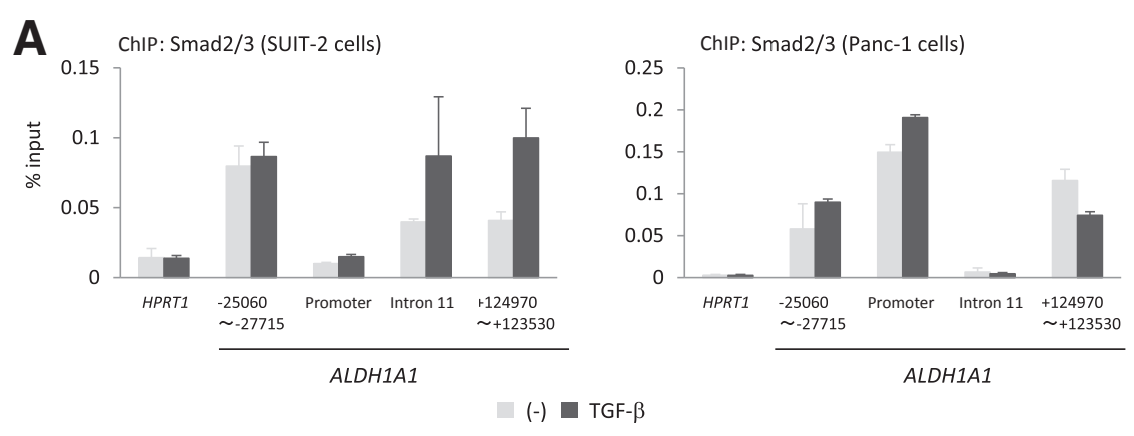

B
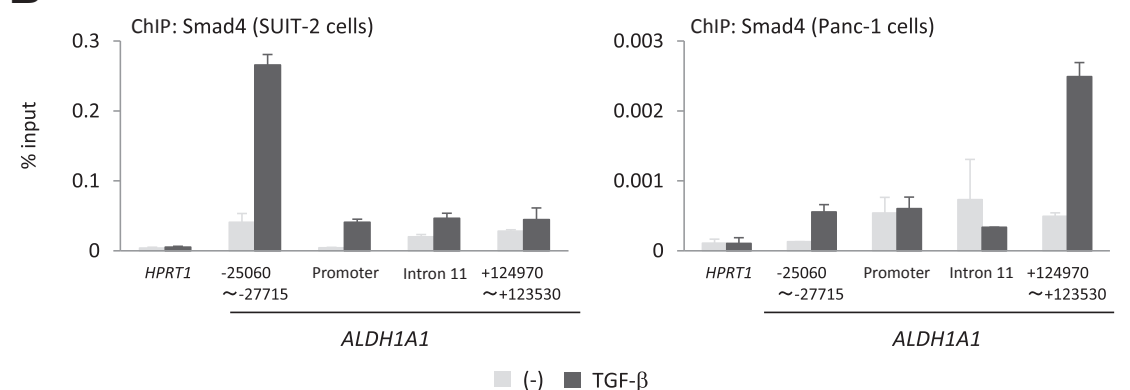

C
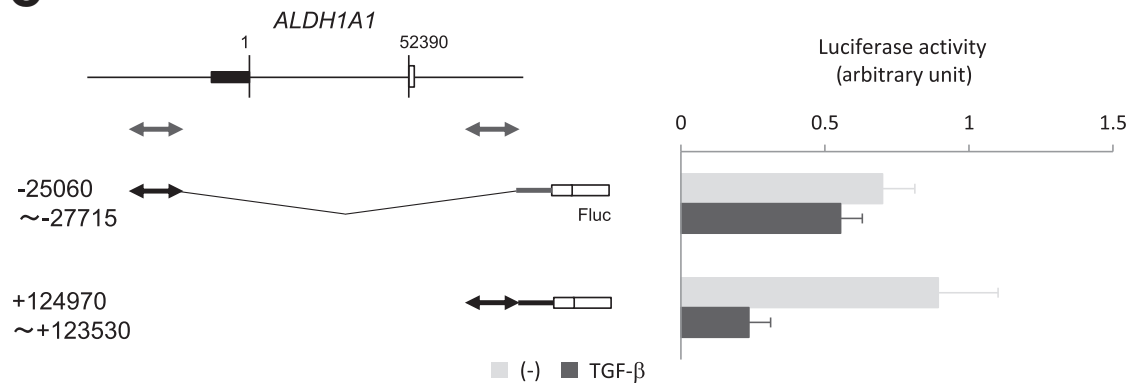

Figure 9 Transcription of ALDH1A1 mRNA is regulated by Smad4 in a transforming growth factor (TGF)- $\beta$-dependent manner. $\mathbf{A}$ and $\mathbf{B}$ : Human pancreatic adenocarcinoma SUIT-2 and Panc-1 cells were stimulated with $1 \mathrm{ng} / \mathrm{mL}$ of TGF$\beta 3$ for 1.5 hours, and cells were fixed and harvested. Genomic DNA was immunoprecipitated by anti-Smad2/3 (A) or anti-Smad4 antibody (B). Smad2/3- or Smad4-bound DNA was determined by quantitative real-time $P C R$ using the primers designed around the ALDH1A1 locus. Numbers indicate the genomic positions relative to the transcriptional start site of ALDH1A1. The HPRT1 intronic region was used as a negative control for chromatin immunoprecipitation (ChIP). C: Panc-1 cells were transfected with $A L D H 1 A 1$ reporterpromoter constructs, and cells were treated with $1 \mathrm{ng} / \mathrm{mL}$ of TGF- $\beta 3$ for 24 hours. Relative luciferase activities were determined. Data are presented as means \pm SD. transcription of ALDH1A1 mRNA through the binding of Smad4 (Figure 9).

We previously performed ChIP-sequencing analysis using anti-Smad4 antibody and found that Smad4 binding was concentrated in specific genomic sequences, including an AP1 site and a GC-rich motif. ${ }^{50}$ This finding suggested the involvement of other transcription factors in the binding of Smad4. Zeb2 (also known as SIP1) forms a complex with Smads and regulates transcription of target genes. ${ }^{51}$ In the present study, AP1 sites were present in the Smad binding sites both upstream and downstream of the ALDHIAl locus, and Zeb2/SIP1 binding motifs were observed downstream of this locus (data not shown). These transcription factors may be required for the Smad4-dependent regulation of $A L D H 1 A 1$ transcription.

Smad4 affected the percentage of ALDH $1{ }^{\text {hi }}$ cells but not that of $\mathrm{CD}_{133^{+}}$cells (Figure 4, data not shown). Lonardo et $\mathrm{al}^{52}$ reported that nodal/activin signaling is important for the characteristics of $\mathrm{CD}_{133^{+}}$pancreatic CICs. However, we found that the ALDH1 ${ }^{\text {hi }}$ cell population was diminished by TGF- $\beta$ but not by activin (data not shown). These data suggest that the TGF- $\beta-$ ALDH1 pathway and nodal/activin-CD133 pathway may function independently in the stemness of pancreatic cancer cells.
Similar to the present findings, previous reports have indicated that TGF- $\beta$ from the cancer microenvironment leads to decreased side population cells and ALDH $1{ }^{\text {hi }}$ cells in diffuse-type gastric carcinoma. ${ }^{10,21}$ Tang et al ${ }^{53}$ reported that TGF- $\beta$ down-regulates the expression of inhibitor of DNA-binding 1 in breast cancer cells, which leads to the differentiation and decrease of CICs. TGF- $\beta$ also restricts the self-renewal activity of $\alpha 6 \beta 1{ }^{\mathrm{hi}} \mathrm{CD} 34^{\mathrm{hi}}$ cells in cutaneous squamous cell carcinomas, ${ }^{54}$ suggesting that TGF- $\beta$ plays a tumor suppressive role in this type of tumor. In the present study, tumor-forming ability of pancreatic cancer cells was significantly attenuated by TGF- $\beta$ (Figure $8 D$ ). We postulated that TGF- $\beta$ negatively regulates the transcription of ALDAH1A1 mRNA thorough Smaddependent signaling pathway (Figure 9). However, tumor-forming ability of BxPC-3 cells was inhibited by TGF- $\beta 3$ (data not shown). Because BxPC-3 cells do not express Smad4 (Figure 1A), Smad-independent signaling pathway might be also involved in the TGF- $\beta$-mediated tumor suppressive role. Numerous reports have also found that the TGF- $\beta$ family plays an opposite role in cancer progression. In several types of cancer, induction of epithelialmesenchymal transition generates cells with stem cell properties. ${ }^{55-57}$ In glioma cells, TGF- $\beta$ maintains the self-renewal 
activity and tumorigenicity of glioma-initiating cells through the leukemia inhibitory factor-induced JAK/STAT pathway and SOX4-SOX2 pathway. ${ }^{58,59}$ Overall, it appears that the roles of TGF- $\beta$ family members are context dependent. It is possible that the bidirectional functions of TGF- $\beta$ family members are determined by many factors, ${ }^{60}$ including types of cancer, types of molecular markers, and the types of isoforms of TGF- $\beta$ family used in each study.

\section{Acknowledgments}

We thank Fumihiko Murai and Hikaru Nishimori (The University of Tokyo) for plasmid construction; Yasuyuki Morishita, Kazunobu Isogaya, and Kei Takahashi (The University of Tokyo) for technical assistance; and Hiroyuki Miyoshi (RIKEN) for the lentivirus vectors.

\section{Supplemental Data}

Supplemental material for this article can be found at http://dx.doi.org/10.1016/j.ajpath.2015.01.011.

\section{References}

1. Clarke MF, Dick JE, Dirks PB, Eaves CJ, Jamieson CH, Jones DL, Visvader J, Weissman IL, Wahl GM: Cancer stem cells-perspectives on current status and future directions: AACR Workshop on cancer stem cells. Cancer Res 2006, 66:9339-9344

2. Russo JE, Hilton J: Characterization of cytosolic aldehyde dehydrogenase from cyclophosphamide resistant L1210 cells. Cancer Res 1988, 48:2963-2968

3. Armstrong L, Stojkovic M, Dimmick I, Ahmad S, Stojkovic P, Hole N, Lako M: Phenotypic characterization of murine primitive hematopoietic progenitor cells isolated on basis of aldehyde dehydrogenase activity. Stem Cells 2004, 22:1142-1151

4. Hess DA, Wirthlin L, Craft TP, Herrbrich PE, Hohm SA, Lahey R, Eades WC, Creer MH, Nolta JA: Selection based on CD133 and high aldehyde dehydrogenase activity isolates long-term reconstituting human hematopoietic stem cells. Blood 2006, 107:2162-2169

5. Hess DA, Craft TP, Wirthlin L, Hohm S, Zhou P, Eades WC, Creer MH, Sands MS, Nolta JA: Widespread nonhematopoietic tissue distribution by transplanted human progenitor cells with high aldehyde dehydrogenase activity. Stem Cells 2008, 26:611-620

6. Jiang F, Qiu Q, Khanna A, Todd NW, Deepak J, Xing L, Wang H, Liu Z, Su Y, Stass SA, Katz RL: Aldehyde dehydrogenase 1 is a tumor stem cell-associated marker in lung cancer. Mol Cancer Res 2009, 7:330-338

7. Huang EH, Hynes MJ, Zhang T, Ginestier C, Dontu G, Appelman H, Fields JZ, Wicha MS, Boman BM: Aldehyde dehydrogenase 1 is a marker for normal and malignant human colonic stem cells (SC) and tracks SC overpopulation during colon tumorigenesis. Cancer Res 2009, 69:3382-3389

8. Rasheed ZA, Yang J, Wang Q, Kowalski J, Freed I, Murter C, Hong SM, Koorstra JB, Rajeshkumar NV, He X, Goggins M, Iacobuzio-Donahue C, Berman DM, Laheru D, Jimeno A, Hidalgo M, Maitra A, Matsui W: Prognostic significance of tumorigenic cells with mesenchymal features in pancreatic adenocarcinoma. J Natl Cancer Inst 2010, 102:340-351

9. Ginestier C, Hur MH, Charafe-Jauffret E, Monville F, Dutcher J, Brown M, Jacquemier J, Viens P, Kleer CG, Liu S, Schott A, Hayes D, Birnbaum D, Wicha MS, Dontu G: ALDH1 is a marker of normal and malignant human mammary stem cells and a predictor of poor clinical outcome. Cell Stem Cell 2007, 1:555-567

10. Katsuno Y, Ehata S, Yashiro M, Yanagihara K, Hirakawa K, Miyazono K: Coordinated expression of REG4 and aldehyde dehydrogenase 1 regulating tumourigenic capacity of diffuse-type gastric carcinoma-initiating cells is inhibited by TGF- $\beta$. J Pathol 2012, 228:391-404

11. Ohi Y, Umekita Y, Yoshioka T, Souda M, Rai Y, Sagara Y, Tanimoto A: Aldehyde dehydrogenase 1 expression predicts poor prognosis in triplenegative breast cancer. Histopathology 2011, 59:776-780

12. Heldin $\mathrm{CH}$, Miyazono K, ten Dijke P: TGF- $\beta$ signalling from cell membrane to nucleus through SMAD proteins. Nature 1997, 390: 465-471

13. Bierie B, Moses H: Tumour microenvironment: TGF $\beta$ : the molecular Jekyll and Hyde of cancer. Nat Rev Cancer 2006, 6:506-520

14. Bardeesy N, DePinho RA: Pancreatic cancer biology and genetics. Nat Rev Cancer 2002, 2:897-909

15. Blackford A, Serrano OK, Wolfgang CL, Parmigiani G, Jones S, Zhang X, Parsons DW, Lin JC, Leary RJ, Eshleman JR, Goggins M, Jaffee EM, Iacobuzio-Donahue CA, Maitra A, Cameron JL, Olino K, Schulick R, Winter J, Herman JM, Laheru D, Klein AP, Vogelstein B, Kinzler KW, Velculescu VE, Hruban RH: SMAD4 gene mutations are associated with poor prognosis in pancreatic cancer. Clin Cancer Res 2009, 15:4674-4679

16. Ijichi H, Otsuka M, Tateishi K, Ikenoue T, Kawakami T, Kanai F, Arakawa Y, Seki N, Shimizu K, Miyazono K, Kawabe T, Omata M: Smad4-independent regulation of $\mathrm{p} 21 / \mathrm{WAF} 1$ by transforming growth factor- $\beta$. Oncogene 2004, 23:1043-1051

17. Horiguchi K, Shirakihara T, Nakano A, Imamura T, Miyazono K, Saitoh M: Role of Ras signaling in the induction of snail by transforming growth factor- $\beta$. J Biol Chem 2009, 284:245-253

18. Ehata S, Hanyu A, Fujime M, Katsuno Y, Fukunaga E, Goto K, Ishikawa Y, Nomura K, Yokoo H, Shimizu T, Ogata E, Miyazono K, Shimizu K, Imamura T: Ki26894, a novel transforming growth factor$\beta$ type I receptor kinase inhibitor, inhibits in vitro invasion and in vivo bone metastasis of a human breast cancer cell line. Cancer Sci 2007, 98:127-133

19. Nishimori H, Ehata S, Suzuki HI, Katsuno Y, Miyazono K: Prostate cancer cells and bone stromal cells mutually interact with each other through bone morphogenetic protein-mediated signals. J Biol Chem 2012, 287:20037-20046

20. Hoshino Y, Katsuno Y, Ehata S, Miyazono K: Autocrine TGF- $\beta$ protects breast cancer cells from apoptosis through reduction of BH3only protein, Bim. J Biochem 2011, 149:55-65

21. Ehata S, Johansson E, Katayama R, Koike S, Watanabe A, Hoshino Y, Katsuno Y, Komuro A, Koinuma D, Kano MR, Yashiro M, Hirakawa K, Aburatani H, Fujita N, Miyazono K: Transforming growth factor- $\beta$ decreases the cancer-initiating cell population within diffuse-type gastric carcinoma cells. Oncogene 2011, 30:1693-1705

22. Koinuma D, Tsutsumi S, Kamimura N, Taniguchi H, Miyazawa K, Sunamura M, Imamura T, Miyazono K, Aburatani H: Chromatin immunoprecipitation on microarray analysis of Smad2/3 binding sites reveals roles of ETS1 and TFAP2A in transforming growth factor $\beta$ signaling. Mol Cell Biol 2009, 29:172-186

23. Morikawa M, Koinuma D, Miyazono K, Heldin CH: Genome-wide mechanisms of Smad binding. Oncogene 2013, 32:1609-1615

24. Shirai YT, Ehata S, Yashiro M, Yanagihara K, Hirakawa K, Miyazono K: Bone morphogenetic protein-2 and -4 play tumor suppressive roles in human diffuse-type gastric carcinoma. Am J Pathol 2011, 179:2920-2930

25. Kawabata KC, Ehata S, Komuro A, Takeuchi K, Miyazono K: TGF$\beta$-induced apoptosis of B-cell lymphoma Ramos cells through reduction of MS4A1/CD20. Oncogene 2013, 32:2096-2106

26. Carbone C, Melisi D: NF- $\kappa \mathrm{B}$ as a target for pancreatic cancer therapy Expert Opin Ther Targets 2012, 16(Suppl 2):S1-S10

27. Lu Y, Zhu H, Shan H, Lu J, Chang X, Li X, Fan X, Zhu S, Wang Y, Guo Q, Wang L, Huang Y, Zhu M, Wang Z: Knockdown of Oct4 and 
Nanog expression inhibits the stemness of pancreatic cancer cells. Cancer Lett 2013, 340:113-123

28. Visvader JE, Lindeman GJ: Cancer stem cells in solid tumours: accumulating evidence and unresolved questions. Nat Rev Cancer 2008, 8:755-768

29. Li C, Heidt D, Dalerba P, Burant C, Zhang L, Adsay V, Wicha M, Clarke M, Simeone D: Identification of pancreatic cancer stem cells. Cancer Res 2007, 67:1030-1037

30. Hermann P, Huber S, Herrler T, Aicher A, Ellwart J, Guba M, Bruns C, Heeschen C: Distinct populations of cancer stem cells determine tumor growth and metastatic activity in human pancreatic cancer. Cell Stem Cell 2007, 1:313-323

31. Bardeesy N, Cheng KH, Berger JH, Chu GC, Pahler J, Olson P, Hezel AF, Horner J, Lauwers GY, Hanahan D, DePinho RA: Smad4 is dispensable for normal pancreas development yet critical in progression and tumor biology of pancreas cancer. Genes Dev 2006, 20 : 3130-3146

32. Marcato P, Dean CA, Giacomantonio CA, Lee PW: Aldehyde dehydrogenase: its role as a cancer stem cell marker comes down to the specific isoform. Cell Cycle 2011, 10:1378-1384

33. Woodford-Richens KL, Rowan AJ, Poulsom R, Bevan S, Salovaara R, Aaltonen LA, Houlston RS, Wright NA, Tomlinson IP: Comprehensive analysis of SMAD4 mutations and protein expression in juvenile polyposis: evidence for a distinct genetic pathway and polyp morphology in SMAD4 mutation carriers. Am J Pathol 2001, 159:1293-1300

34. Miyaki M, Iijima T, Konishi M, Sakai K, Ishii A, Yasuno M, Hishima T, Koike M, Shitara N, Iwama T, Utsunomiya J, Kuroki T, Mori T: Higher frequency of Smad4 gene mutation in human colorectal cancer with distant metastasis. Oncogene 1999, 18:3098-3103

35. Xie W, Bharathy S, Kim D, Haffty BG, Rimm DL, Reiss M: Frequent alterations of Smad signaling in human head and neck squamous cell carcinomas: a tissue microarray analysis. Oncol Res 2003, 14:61-73

36. Takaku K, Miyoshi H, Matsunaga A, Oshima M, Sasaki N, Taketo MM: Gastric and duodenal polyps in Smad4 (Dpc4) knockout mice. Cancer Res 1999, 59:6113-6117

37. Takaku K, Oshima M, Miyoshi H, Matsui M, Seldin MF, Taketo MM: Intestinal tumorigenesis in compound mutant mice of both Dpc4 (Smad4) and Apc genes. Cell 1998, 92:645-656

38. Xu X, Ehdaie B, Ohara N, Yoshino T, Deng CX: Synergistic action of Smad4 and Pten in suppressing pancreatic ductal adenocarcinoma formation in mice. Oncogene 2010, 29:674-686

39. Duda DG, Sunamura M, Lefter LP, Furukawa T, Yokoyama T, Yatsuoka T, Abe T, Inoue H, Motoi F, Egawa S, Matsuno S, Horii A: Restoration of SMAD4 by gene therapy reverses the invasive phenotype in pancreatic adenocarcinoma cells. Oncogene 2003, 22: 6857-6864

40. Xu RH, Sampsell-Barron TL, Gu F, Root S, Peck RM, Pan G, Yu J, Antosiewicz-Bourget J, Tian S, Stewart R, Thomson JA: NANOG is a direct target of TGFß/activin-mediated SMAD signaling in human ESCs. Cell Stem Cell 2008, 3:196-206

41. Sakaki-Yumoto M, Liu J, Ramalho-Santos M, Yoshida N, Derynck R: Smad2 is essential for maintenance of the human and mouse primed pluripotent stem cell state. J Biol Chem 2013, 288: $18546-18560$

42. Chute JP, Muramoto GG, Whitesides J, Colvin M, Safi R, Chao NJ, McDonnell DP: Inhibition of aldehyde dehydrogenase and retinoid signaling induces the expansion of human hematopoietic stem cells. Proc Natl Acad Sci U S A 2006, 103:11707-11712

43. Dylla SJ, Beviglia L, Park IK, Chartier C, Raval J, Ngan L, Pickell K, Aguilar J, Lazetic S, Smith-Berdan S, Clarke MF, Hoey T, Lewicki J, Gurney AL: Colorectal cancer stem cells are enriched in xenogeneic tumors following chemotherapy. PLoS One 2008, 3:e2428

44. Muramoto GG, Russell JL, Safi R, Salter AB, Himburg HA, Daher P, Meadows SK, Doan P, Storms RW, Chao NJ, McDonnell DP, Chute JP: Inhibition of aldehyde dehydrogenase expands hematopoietic stem cells with radioprotective capacity. Stem Cells 2010, 28: $523-534$
45. Kim SK, Kim H, Lee DH, Kim TS, Kim T, Chung C, Koh GY, Kim H, Lim DS: Reversing the intractable nature of pancreatic cancer by selectively targeting ALDH-high, therapy-resistant cancer cells. PLoS One 2013, 8:e78130

46. Moreb JS, Turner C, Sreerama L, Zucali JR, Sladek NE, Schweder M: Interleukin-1 and tumor necrosis factor $\alpha$ induce class 1 aldehyde dehydrogenase mRNA and protein in bone marrow cells. Leuk Lymphoma 1995, 20:77-84

47. Wang X, Lu H, Li T, Yu L, Liu G, Peng X, Zhao J: Kruppel-like factor 8 promotes tumorigenic mammary stem cell induction by targeting miR-146a. Am J Cancer Res 2013, 3:356-373

48. Elizondo G, Corchero J, Sterneck E, Gonzalez FJ: Feedback inhibition of the retinaldehyde dehydrogenase gene ALDH1 by retinoic acid through retinoic acid receptor $\alpha$ and CCAAT/enhancer-binding protein $\beta$. J Biol Chem 2000, 275:39747-39753

49. Mu X, Isaac C, Greco N, Huard J, Weiss K: Notch signaling is associated with ALDH activity and an aggressive metastatic phenotype in murine osteosarcoma cells. Front Oncol 2013, 3:143

50. Koinuma D, Tsutsumi S, Kamimura N, Imamura T, Aburatani H, Miyazono K: Promoter-wide analysis of Smad4 binding sites in human epithelial cells. Cancer Sci 2009, 100:2133-2142

51. Verschueren K, Remacle JE, Collart C, Kraft H, Baker BS, Tylzanowski P, Nelles L, Wuytens G, Su MT, Bodmer R, Smith JC, Huylebroeck D: SIP1, a novel zinc finger/homeodomain repressor, interacts with Smad proteins and binds to $5^{\prime}$-CACCT sequences in candidate target genes. J Biol Chem 1999, 274:20489-20498

52. Lonardo E, Hermann PC, Mueller MT, Huber S, Balic A, MirandaLorenzo I, Zagorac S, Alcala S, Rodriguez-Arabaolaza I, Ramirez JC, Torres-Ruíz R, Garcia E, Hidalgo M, Cebrián D, Heuchel R, Löhr M, Berger F, Bartenstein P, Aicher A, Heeschen C: Nodal/Activin signaling drives self-renewal and tumorigenicity of pancreatic cancer stem cells and provides a target for combined drug therapy. Cell Stem Cell 2011, 9:433-446

53. Tang B, Yoo N, Vu M, Mamura M, Nam JS, Ooshima A, Du Z, Desprez PY, Anver MR, Michalowska AM, Shih J, Parks WT, Wakefield LM: Transforming growth factor- $\beta$ can suppress tumorigenesis through effects on the putative cancer stem or early progenitor cell and committed progeny in a breast cancer xenograft model. Cancer Res 2007, 67:8643-8652

54. Schober M, Fuchs E: Tumor-initiating stem cells of squamous cell carcinomas and their control by TGF- $\beta$ and integrin/focal adhesion kinase (FAK) signaling. Proc Natl Acad Sci U S A 2011, 108: 10544-10549

55. Mani SA, Guo W, Liao MJ, Eaton EN, Ayyanan A, Zhou AY, Brooks M, Reinhard F, Zhang CC, Shipitsin M, Campbell LL, Polyak K, Brisken C, Yang J, Weinberg RA: The epithelialmesenchymal transition generates cells with properties of stem cells. Cell 2008, 133:704-715

56. Scheel C, Eaton EN, Li SH, Chaffer CL, Reinhardt F, Kah KJ, Bell G, Guo W, Rubin J, Richardson AL, Weinberg RA: Paracrine and autocrine signals induce and maintain mesenchymal and stem cell states in the breast. Cell 2011, 145:926-940

57. Cao L, Shao M, Schilder J, Guise T, Mohammad KS, Matei D: Tissue transglutaminase links TGF- $\beta$, epithelial to mesenchymal transition and a stem cell phenotype in ovarian cancer. Oncogene 2012, 31:2521-2534

58. Peñuelas S, Anido J, Prieto-Sánchez RM, Folch G, Barba I, Cuartas I, García-Dorado D, Poca MA, Sahuquillo J, Baselga J, Seoane J: TGF- $\beta$ increases glioma-initiating cell self-renewal through the induction of LIF in human glioblastoma. Cancer Cell $2009,15: 315-327$

59. Ikushima $\mathrm{H}$, Todo $\mathrm{T}$, Ino $\mathrm{Y}$, Takahashi $\mathrm{M}$, Miyazawa $\mathrm{K}$, Miyazono K: Autocrine TGF- $\beta$ signaling maintains tumorigenicity of glioma-initiating cells through Sry-related HMG-box factors. Cell Stem Cell 2009, 5:504-514

60. Ehata S, Yokoyama Y, Takahashi K, Miyazono K: Bi-directional roles of bone morphogenetic proteins in cancer: another molecular Jekyll and Hyde? Pathol Int 2013, 63:287-296 